\title{
Up-Regulation of the Gap Junction Intercellular Communication by Tea Polyphenol in the Human Metastatie Lung Carcinoma Cell Line
}

\author{
Xiangyong Li ${ }^{1,2}$, Qinghua Wang ${ }^{1}$ Jun Yang ${ }^{1 *}$, Yanjuan Pan $^{1}$, Qingyong Chen ${ }^{3}$, Xiqing Yan ${ }^{1}$, \\ Daxin Wang ${ }^{4}$, Xijian Zhou ${ }^{2}$, Yuquan $\mathrm{Wu}^{3}$ \\ ${ }^{1}$ College of Pharmacy and Academic Workstation for Natural Medicine Research of Henan Province, Xinxiang Medical University, \\ Xinxiang, China; ${ }^{2} 101$ Hospital of PLA, Wuxi, China; ${ }^{3} 117$ Hospital of PLA, Hangzhou, China; ${ }^{4}$ Jiangsu Su Bei People's Hospital, \\ Yangzhou University, Yangzhou, China. \\ Email: *bcd2009@126.com
}

Received November $21^{\text {st }}, 2011$; revised December $19^{\text {th }}, 2011$; accepted January $10^{\text {th }}, 2012$

\begin{abstract}
Our previous study has proven that tea polyphenol has a role in lung neoplasms. The present communication was to investage the anti-proliferation effect of tea polyphenol on the PG cells, which was a high metastatic human lung carcinoma cell line, by 3-(4,5)-dimethylthiahiazo(-z-y1)-3,5-diphenytetrazoliumromide (MTT) cell viability assay, and to study the change of intracellular calcium concentration, connexin43 (Cx43) expression, gap junctional intercellular communication (GJIC) and cell cycle distribution after the tea polyphenol treatment by laser scanning confocal microscopy and flow cytometry. The results showed that 1) tea polyphenol could kill the PG cells in a dose-depent manner via inhibiting the PG cell proliferation and blocking the PG cell cycle progression staying in G0/G1 phase and not transfering in S and G2/M phases to reduce the PG cell proliferation index; 2) the increases of intracellular calcium concentration, GJIC and Cx43 expression were related with the tea polyphenol doses. The data suggested that tea polyphenol could inhibit the growth of PG cells, which mechanism was associated with the up-regulation of GJIC.
\end{abstract}

Keywords: Tea Polyphenol; Lung Neoplasms; Highly Metastatic Human Lung Carcinoma Cell Line; Gap Junction Intercellular Communication

\section{Introduction}

Gap junction intercellular communication (GJIC) is an important cell-to-cell connection that plays a role in cell differentiation, growth control and maintaining body environmental balance [1-3]. GJIC can permit the transmission of growth-promoting or growth-suppressive factors, that has been traditionally implicated to be the major route by which gap junctions regulate cell growth [4-6]. Many studies have discovered that the GJIC can influence the occurrence and metastasis of cancer [7-11].

Gap junctions are clusters of channels formed by the special type of proteins named connexins (Cx). They allow the less than $1 \mathrm{kDa}$ molecules to pass directly between two adjacent cells [12]. The gap junction protein connexin43 (Cx43), which belongs to a large family of channel proteins consisting of at least 21 members, is expressed ubiquitously in the heart, muscle, brain and lung $[13,14]$. Aberrant $\mathrm{Cx} 43$ expression has been found in several types of tumor [15-19]. Cx43 expression is

${ }^{*}$ Corresponding author. associated with the tumor grade and proliferation. The 18 primary tumor sample screen revealed a low $\mathrm{Cx} 43$ expression in grade III and IV tumors [20]. Cx43 is one of the major common connexins and its homolog expressed in lung tissue [21-23]. Cx43 plays an important role in carcinogenesis and tumour metastasis [24-26]. GJIC and $\mathrm{Cx} 43$ expression are markedly suppressed in human lung carcinoma [27].

As an important cell messenger, $\mathrm{Ca}^{2+}$ can regulate the cell growth, secretion and transportation. It influences the DNA duplicate or RNA expression including some protooncogene and tumor-suppressor gene expression [28]. Recent studies showed that the correlation between the cell $\mathrm{Ca}^{2+}$ concentration and the cancer cell proliferation, apoptosis, invasion and transfer $[28,29]$. GJIC was regulated by the expression of $\mathrm{Ca}^{2+}$ dependent cell adhesion molecule in mouse epidemic cells [30].

Tea [Camellia sinesis (Theacacea)] is considered to be the second popular beverage compared with water. Tea polyphenols are chemical compounds such as flavanoids and tannins found in tea, which have effects on cancer 
prevention, inhibition and anti-metastasis. The tea polyphenol concentration is $10 \%-30 \%$ in the different kind tea. The cancer preventive activities have been demonstrated in many different animal models. Results from epidemiological studies as well as laboratory experiments suggest that tea consumption confers protection against the cancer development [31-36]. Out of total 21 studies on the effect of tea on lung tumorigenesis, 19 studies showed inhibitory effects [37-41].

Lung cancer is one of the most common death of cancer all over the world [42-43]. Evidence from in vitro and in vivo experiments suggested that tea polyphenols protect against lung cancer through their antimutagenic and antioxidant properties [44-48]. The present study try to investigate tea polyphenols effect on the high metastatic human lung carcinoma through studying intracellular calcium concentration, $\mathrm{Cx} 43$ expression and GJIC function in vitro, so as to understand the mechanism of tea polyphenols treating high metastatic human lung carcinoma.

\section{Materials and Methods}

\subsection{Materials}

Tea polyphenols were products from Chinese Tea Institute, Hangzhou, Zhejiang, China. The $0.25 \%$ trypsin, RPMI 1640 medium, 3-(4,5)-dimethylthiahiazo(-z-y1)3,5-diphenytetrazoliumromide (MTT), dimethly sufoxide (DMSO), $\mathrm{Ca}^{2+}$ fluorescent probe fluo-3AM and 5, 6-oxygen fluorescein vinegar salt (5,6-CFDA) were purchased from Sigma Co. Mouse anti-human Cx43 monoclonal antibody, FITC-labeled goat anti-mouse $\mathrm{mAb}$ IgG were purchased from Zymed C., USA. The irrelevant mouse $\mathrm{mAb}$ IgG was purchased from Beijing Zhongshan Company. FACsort flow cytometry came from BD Co., USA and the laser scanning confocal mircroscopy was ZEISS LSM 510 product, German.

\subsection{Cell Culture}

PG cells from highly metastatic human lung cancer cell lines, which was with $10 \%$ inactivated fetal calf serum in RPMI1640 culture medium, was provided by Zhejiang Cancer Institute, Hangzhou, Zhejiang, China.

\subsection{Grouping}

There were four groups: Control group was not treated by tea polyphenols; Polyphenol groups including 3 groups were treated by the tea polyphenols with $25,50,100$ and $200 \mu \mathrm{g} / \mathrm{ml}$ concentration.

\subsection{Cytotoxicity Test (MTT)}

Take logarithmic growth of human lung cancer cell lines
(PG cells) $1.0 \times 10^{6} / \mathrm{ml}$ packing in 96 holes for experimental groups and five parallel holes for each group. Put them at $37^{\circ} \mathrm{C}$ for $72 \mathrm{~h}$, then add MTT solution to culture for $4 \mathrm{~h}$. Before testing, add DMSO to them. The OD value of each well was determined by DG3022 enzyme-linked detector using $570 \mathrm{~nm}$ wavelength after the crystals dissolved. Calculate growth inhibition rate according to the following formula: Growth inhibition rate $(\%)=(1-$ polyphenol group mean OD value/control group mean OD value) $\times 100 \%$.

\subsection{Cell Cycle Phase Determination}

Cell cycle phase was determined by flow cytometry detect after tea polyphenols treating PG cells. The cell cycle proportion, proliferation index (PI) calculated were calculated as follows: PI $(\%)=(\mathrm{S}+\mathrm{G} 2 / \mathrm{M}) /(\mathrm{G} 0 / \mathrm{G} 1+\mathrm{S}+$ $\mathrm{G} 2 / \mathrm{M}) \times 100 \%$.

\subsection{Intracellular $\mathrm{Ca}^{2+}$ Concentration Measurement}

The cell concentration was adjusted to $2 \times 10^{6} / \mathrm{ml}$. Centrifuge, drawout the supernatant, add $2 \mathrm{ml}$ Hank solution to soluate the deposit. After adding a final concentration of $10 \mu \mathrm{mol} / \mathrm{L}$ of $\mathrm{Ca}^{2+}$ fluorescence light probe, shock it in a water bath at $37^{\circ} \mathrm{C}$ incubation for $45 \mathrm{~min}$, and then wash two times by Hank solution. At the end, intracellular $\mathrm{Ca}^{2+}$ concentration was meaused in $2 \mathrm{ml}$ float solution using laser confocal microscopy.

\subsection{GJIC Function Test}

Depending on the technique of fluorescence recovery after photo bleaching (FRAP), the fluorescence recovery speed (GJIC function) of lung cancer PG cells was measured by laser confocal microscope. After the PG cells being to conventional monolayer culture, the cells were washed four times with PBS containing $\mathrm{Ca}^{2+}, \mathrm{Mg}^{2+}$. Plus $10 \mu \mathrm{g} / \mathrm{ml}$ fluorescent dye 5,6-CFDA $0.5 \mathrm{ml}$ for $37^{\circ} \mathrm{C}$ incubation 20min. Wash 4 times with PBS containing $\mathrm{Ca}^{2+}, \mathrm{Mg}^{2+}$ to wash drawout the excess extracellular dye. After adding a small amount of serum-free medium, the GJIC function was measured by FRAP. Using microscope ( $\times 40$-fold oil immersion), complete the bleach definition in the list of cells or regions of interest (ROI), and the process of "Bleach/Time Series Scan". The scan images of ROI after bleaching at different intervals (1.5 $\mathrm{min}$ ) showed the fluorescence recovery of bleached fluorescent cells and the fluorescence changes of their adjacent unbleached cells. All FRAP experiments, which included dye loading, rinsing, cell selection, quenching cell and scanning, should be completed within 30min when the cell monolayer were not in the culture state. 


\subsection{Cell Gap Junction Protein (Cx43) Determination}

Polyphenol groups were added different tea polyphenols dosage $(25,50,100$ or $200 \mu \mathrm{g} / \mathrm{ml})$ in RPMI 1640 cell culture medium, whereas control group was added only physiological saline in RPMI 1640 cell culture medium. The PG cells were cultured for $72 \mathrm{~h}$. The cell suspension was obtained after $0.25 \%$ trypsin digestion. RPMI 1640 medium was added to $20 \mathrm{ml} / \mathrm{L}$ normal goat serum at $4^{\circ} \mathrm{C}$ $30 \mathrm{~min}$ for closing. Add 1:100 FITC-conjugated goat antimouse $\mathrm{mAb}$ IgG for incubation in $4^{\circ} \mathrm{C} 30 \mathrm{~min}$, and then wash 2 times by $0.01 \mathrm{mmol} / \mathrm{L}$ PBS. For negative control, add anti-Cx43 mAb, irrelevant mouse mAb IgG for incubation in $4^{\circ} \mathrm{C} 30 \mathrm{~min}$, and then wash 2 times by 0.01 $\mathrm{mmol} / \mathrm{L}$ PBS. The expression of $\mathrm{Cx} 43$ was deteminated by FACSort flow cytometry.

\subsection{Statistical Analysis}

Each experiment was repeated 3 times. The data were treated with SPSS 9.0 software package $t$ test and $\chi^{2}$ test.

\section{Results}

\subsection{Tea Polyphenols Killed PG Cells via Inhibiting the Cell Activity and Proliferation Cycle}

Tea polyphenols could kill PG cells via inhibiting the cell activity and proliferation cycle in a dose-dependent manner, in which tea polyphenols in the concentration of $50 \mu \mathrm{g} / \mathrm{ml}$ began to show some of the destruction. After
$72 \mathrm{~h}$ that tea polyphenols effected, it showed that the rate of PG cells in G2/M and S phase decreased, and PG cells were blocked in G0/G1 phase. Copmared with the control group, the PG cell proliferation index (PI) decreased in different polyphenol group. Specially in the tea polyphenols in the concentration with $50 \mu \mathrm{g} / \mathrm{ml}, 100 \mu \mathrm{g} / \mathrm{ml}$ or $200 \mu \mathrm{g} / \mathrm{ml}$ treatment, the PI was significantly lower than that in control group $(P<0.05$ or 0.01$)$ (Table 1).

\subsection{Tea Polyphenols Increased PG Cell Intracellular $\mathrm{Ca}^{2+}$ Concentration, GJIC Function and Cx43 Expression}

After the treatment with tea polyphenols, PG cell intracellular $\mathrm{Ca}^{2+}$ concentration, GJIC function and $\mathrm{Cx} 43$ expression were increased in a dose-dependent manner, specially in the polyphenol group the tea polyphenols in the concentration with $50 \mu \mathrm{g} / \mathrm{ml}, 100 \mu \mathrm{g} / \mathrm{ml}$ or $200 \mu \mathrm{g} / \mathrm{ml}$ treatment, the PG cell intracellular $\mathrm{Ca}^{2+}$ concentration, GJIC function and Cx43 expression were significantly higher than those in control group $(P<0.05$ or 0.01$)$ (Table 2).

\section{Discussion}

Although the anti-cancer effects of tea polyphenols have been widely studied, the core mechanism is still unclear. Many scientists believe that the anti-cancer effects of tea polyphenols are through antioxidant, anti-mutagenic and anti-metastasis [49]. The present MTT test showed that tea polyphenols in $25 \mu \mathrm{g} / \mathrm{ml} \mathrm{-} 200 \mu \mathrm{g} / \mathrm{ml}$ concentration inhibited PG cell cytotoxic activity and in $50 \mu \mathrm{g} / \mathrm{ml}$ or

Table 1. Effect of tea polyphenols on the PG cell activity and proliferation cycle.

\begin{tabular}{|c|c|c|c|c|c|c|}
\hline \multirow[t]{2}{*}{ Group } & \multirow{2}{*}{$\begin{array}{c}\text { Growth inhibition } \\
\text { rate }(\%)\end{array}$} & \multirow{2}{*}{ Kill probability (\%) } & \multicolumn{3}{|c|}{ Cell cycle analysis $(\%)$} & \multirow{2}{*}{$\operatorname{PI}(\%)$} \\
\hline & & & $\mathrm{G} 0 / \mathrm{G}$ & $\mathrm{S}$ & $\mathrm{G} 2 / \mathrm{M}$ & \\
\hline Control & $0.972 \pm 0.045$ & 16.6 & 45.22 & 33.32 & 21.46 & 54.78 \\
\hline $25 \mathrm{ug} / \mathrm{ml}$ & $0.705 \pm 0.055^{*}$ & $22.5^{*}$ & 48.48 & 32.12 & 19.40 & 51.52 \\
\hline $50 \mathrm{ug} / \mathrm{ml}$ & $0.423 \pm 0.046^{* *}$ & $56.5^{* *}$ & $55.60^{*}$ & 24.29 & 20.12 & $44.40^{*}$ \\
\hline $100 \mathrm{ug} / \mathrm{ml}$ & $0.274 \pm 0.056^{* *}$ & $71.9^{* *}$ & $67.32^{* *}$ & $22.87^{*}$ & $9.87^{* *}$ & $32.74^{* *}$ \\
\hline
\end{tabular}

Compared with control group, ${ }^{*} P<0.05$ and ${ }^{* *} P<0.01$.

Table 2. Tea polyphenols increased PG cell intracellular $\mathrm{Ca}^{2+}$ concentration, GJIC function and Cx43 expression in PG cells.

\begin{tabular}{cccc}
\hline Group & $\mathrm{Ca}^{2+}$ concentration $(\mathrm{nmol} / \mathrm{L})$ & GJIC function $(\% / \mathrm{min})$ & Cx43 expression $(\%)$ \\
\hline Control & $71.22 \pm 28.65$ & $17.68 \pm 2.37$ & $93.76 \pm 10.22$ \\
$25 \mu \mathrm{g} / \mathrm{ml}$ & $98.67 \pm 17.03$ & $23.32 \pm 2.31$ & $103.31 \pm 11.34$ \\
$50 \mu \mathrm{g} / \mathrm{ml}$ & $125.12 \pm 24.71^{* *}$ & $54.18 \pm 3.03^{*}$ & $739.64 \pm 11.21^{*}$ \\
$100 \mu \mathrm{g} / \mathrm{ml}$ & $162.41 \pm 30.23^{* *}$ & $78.60 \pm 3.15^{* *}$ & $89.17 \pm 13.51^{* *}$ \\
$200 \mu \mathrm{g} / \mathrm{ml}$ & $181.11 \pm 26.43^{* *}$ & $86 \pm 4.05^{* *}$ & $205.48 \pm 14.03^{* *}$ \\
\hline
\end{tabular}

Compared with control group, ${ }^{*} P<0.05$ and ${ }^{* *} P<0.01$. 
more concentration had killed PG cell effect, which role strengthen showed the dose-dependent relationship. The present flow cytometry studied the effect of tea polyphenols in $25 \mu \mathrm{g} / \mathrm{ml}-200 \mu \mathrm{g} / \mathrm{ml}$ concentration on PG cell growth cycle, which showed that in the tea polyphenols could increase PG cells in G0/G1 phase (block in G0/G1 phase), decreased PG cell PI in a dose-dependent manner. The data indicated that tea polyphenols might inhibit PG cell growth, which was mainly blocked the transformation from G1 to $\mathrm{S}$ phase and affected DNA synthesis, so as to inhibit the cell proliferation.

GJIC function plays an important role in tumor metastasis. GJIC has been implicated in the regulation of homeostasis and a diverse array of cellular functions related to cell specialization, growth and differentiation [3]. In different stages of tumor metastasis, GJIC function shows different effect, sometimes enhance and sometimes weaken, because of $\mathrm{Cx}$ gene mutations and the role of cell surface adhesion molecules [50]. Tomai et al. study has shown that only 2 lung cancer cell lines have a wide GJIC function in 17 lung cancer cell lines, and 16 fresh lung tissues do not show GJIC function [51]. The fiber cells that are isolated from the same lung tissue have a wide GJIC function, and GJIC relates with lung cancer metastasis closely, which shows some prognostic value. Connexin gene is a tumor-suppressor gene family, several studies have indicated an inverse correlation between Cx43 expression and tumor grade [52,53]. The experiment that the wild-type connexin genes were transfected into tumor cells, has shown that it inhibits tumor growth, increases GJIC and caused the tumor cells in normal growth status [54]. Zhang ZQ et al. found that $\mathrm{Cx} 43$ mRNA and protein levels were in a high expression, $\mathrm{Cx} 43$ protein immunofluorescence distributed in the site of gap junction, GJIC function enhanced, and $\mathrm{Cx} 43$ showed functional expression in the normal human embryonic lung cells [55]. Many human tumors, including lung cancer, have been reported to be deficient in expression of Cx43 mRNA and protein levels [15-19,56]. In contrast with the normal, the human lung cancer PG cell Cx43 did not express in both mRNA and protein levels, and showed the defect in the cell communication. Banoub et al. discovered that DB-cAMP inhibited cell proliferation, induced increase of $\mathrm{Cx} 43$ expression and GJIC function, and the growth inhibition related with the increase of GJIC function after DB-cAMP affecting the mouse lung epithelial cells in the malignant transformation [57]. Increase of the GJIC function and $\mathrm{Cx} 43$ expression could promote extracellular signal transduction so as to regulate many cell functions including cell proliferation, differentiation, metabolism. The present study showed that tea polyphenols not only inhibited the lung cancer PG cell growth but also increased GJIC function and $\mathrm{Cx} 43$ expression in a dose-dependent manner, through the lung cancer PG cells had low GJIC function and Cx43 expression. The data suggested that anti-tumor effect of tea polyphenols might relate with the GJIC function regulation and $\mathrm{Cx} 43$ expression level.

Many studies have shown that intracellular $\mathrm{Ca}^{2+}$ concentration relates with the cancer cell proliferation, apoptosis, invasion and metastasis [58]. $\mathrm{Ca}^{2+}$ concentration can activate the endogenous enzymes and induce DNA degradation in the nuclear body so as to block the cell growth cycle. The present showed that tea polyphenols increased the intracellular $\mathrm{Ca}^{2+}$ concentration in lung cancer PG cells in a dose-dependent manner. The increase of the intracellular $\mathrm{Ca}^{2+}$ concentration, which acted as a second messenger substances in PG cell signaling processes, might enhanced GJIC function and Cx43 expression so as to inhibit the $\mathrm{PG}$ cell growth and metastasis.

In conclusion, the present made the clear that 1) tea polyphenol could kill the PG cells from a high metastatic human lung carcinoma cell line in a dose-depent manner, which inhibited the PG cell proliferation and blocked the PG cell cycle progression staying in $\mathrm{G} 0 / \mathrm{G} 1$ phase and not transfering in $\mathrm{S}$ and $\mathrm{G} 2 / \mathrm{M}$ phases, so as to reduce the PG cell proliferation index; 2) the increases of intracellular $\mathrm{Ca}^{2+}$ concentration, GJIC and $\mathrm{Cx} 43$ expression were related with the tea polyphenol dose. The data suggested that tea polyphenol could inhibit the growth of PG cells from a high metastatic human lung carcinoma cell line, which mechanism was associated with the up-regulation of GJIC. Although intracellular $\mathrm{Ca}^{2+}$ concentration, GJIC function and $\mathrm{Cx} 43$ expression show a parallel relationship, it is not clear how $\mathrm{Ca}^{2+}$ acted as a second messenger substances of PG cell signaling processes to enhance GJIC function and $\mathrm{Cx} 43$ expression.

While $\mathrm{Cx} 43$ has received much attention for its role as a growth suppressor, several studies have implicated a role for $\mathrm{Cx} 43$ in both physiological and pathological cell motility $[59,60]$. In the context of gliomas, studies directly examining $\mathrm{Cx} 43$ have indicated a positive correlation with motility and/or invasion [61-63]. Recent studies have revealed a new emerging role of $\mathrm{Cx} 43$ in promoting cell migration, such as in normal brain development $[64,65]$ and in enhancing glioma invasion $[61,62,66,67]$. It is clear that $\mathrm{Cx} 43$ expression is highly heterogeneous, and its level of expression may be dependent on the local tumor microenvironment, such as the presence of $\mathrm{Cx} 43$ expressing non-transformed astrocytes within the tumor core (Sin et al., unpublished data). Therefore, it is conceivable that $\mathrm{Cx} 43$ may perform different functions depending on the cellular status of the tumor [68]. Our results show that tea polyphenol could inhibit the growth of PG cells, which mechanism was associated with the up-expression of $\mathrm{Cx} 43$ and up-regulation of GJIC. The 
exact mechanism needs further study.

\section{Acknowledgements}

This work was supported by the Xinxiang Medical University, 101 Hospital of PLA, 117 Hospital of PLA and Jiangsu Su Bei Hospital.

\section{REFERENCES}

[1] H. Bartels, H.-J. Oestern and G. Voss-Wermbter, "Communicating-Occluding Junction Complexes in the Alveolar Epithelium," American Reviews of Respiratory Disease, Vol. 21, 1980, pp. 1017-1024.

[2] W. R. Loewenstein and Y. Kanno, "Intercellular Communication and Tissue Growth," Journal of Cell Biology, Vol. 33, No. 2, 1967, pp. 225-234. doi: $10.1083 /$ jcb.33.2.225

[3] J. C. Herve, N. Bourmeyster, D. Sarrouilhe and H. S. Duffy, "Gap Junctional Complexes: From Partners to Functions," Progress in Biophysics and Molecular Biology, Vol. 94, No. 1-2, 2007, pp. 29-65. doi:10.1016/j.pbiomolbio.2007.03.010

[4] W. R. Loewenstein, "Junctional Intercellular Communication and the Control of Growth," Biochimica et Biophysica Acta, Vol. 560, No. 1, 1979, pp. 1-65.

[5] C. C. Naus, "Gap Junctions and Tumour Progression," Canadian Journal of Physiology and Pharmacology, Vol. 80, No. 2, 2002, pp. 136-141. doi:10.1139/y02-009

[6] M. Mesnil, S. Crespin, J. L. Avanzo and M. L. ZaidanDagli, "Defective Gap Junctional Intercellular Communication in the Carcinogenic Process," Biochimica et Biophysica Acta, Vol. 1719, No. 1-2, 2005, pp.125-145. doi:10.1016/j.bbamem.2005.11.004

[7] P. R. Brink, K. Cronin, K. Banach K, E. Peterson, E. M. Westphale, K. H. Seul, S. V. Ramanan and E. C. Beyer, "Evidence for HEteromeric Gap Junction Channels Formed Rat Connexin43 and Human Connexin37," American Journal of Physiology, Vol. 274, No. 4, 1997, pp. 1386-1392.

[8] C. Borek, S. Higashino and W. R. Loewenstein, "Intercellular Communication and Tissue growth IV. Conductance of Membrane Junctions of Normal and Cancerous Cells in Culture," Journal of Membrane Biology, Vol. 1, No. 1, 1969, pp. 274-293. doi:10.1007/BF01869786

[9] Y. Kanno and Y. Matsui, "Cellular Uncoupling in Cancerous Stomach Epithelium,” Nature, Vol. 218, No. 5143, 1968, pp. 775-776. doi:10.1038/218775b0

[10] W. R. Loewenstein and Y. Kanno, "Intercellular Communication and the Control of Tissue Growth: Lack of Communication between Cancer Cells," Nature, Vol. 209, No. 5029, 1966, pp. 1248-1249. doi:10.1038/2091248a0

[11] M. Mesnil, R. Montesano and H. Yamasaki, "Intercellular Communication of Transformed and Non-Transformed Rat Liver Epithelial Cells," Experimental Cell Research, Vol. 165, No. 2, 1986, pp. 391-402. doi:10.1016/0014-4827(86)90593-8

[12] D. A. Goodenough, J. A. Goliger and D. L. Paul, "Con- nexins, Connexons and Intercellular Communication," Annual Reviews Biochemistry, Vol. 65, No. 1, 1996, pp. 475-502. doi:10.1146/annurev.bi.65.070196.002355

[13] A. M. Simon and D. A. Goodenough, "Diverse Functions of Vertebrate Gap Junctions," Trends Cell Biology, Vol. 8, No. 12, 1998, pp. 477-483. doi:10.1016/S0962-8924(98)01372-5

[14] E. C. Beyer, J. Kistler, D. L. Paul and D. A. Goodenough, "Antisera Directed against Connexin43 Peptides React with a 43-kDa Protein Localized to Gap Junctions in Myometrium and Other Tissues," Journal of Cell Biology, Vol. 108, No. 2, 1989, pp. 595-605.

doi: $10.1083 /$ jcb.108.2.595

[15] R. J. Ruch, "The Role of Gap Junction Intercellular Communication in Neoplasia," Annals of Clinical and Laboratory Sciences, Vol. 24, No. 3, 1994, pp. 216-231.

[16] H. Tsai, J. Werber, M. O. Davia, M. Edelman, K. M. Tanaka, A. Melman, G. J. Christ and J. Geliebter, "Reduced Connexin43 Expression in High Grade, Human Prostatic Adenocarcinoma Cells," Biochemical and Biophysical Research Communications, Vol. 229, No. 1, 1996, pp. 64 69. doi:10.1006/bbrc. 1996.1468

[17] K. K. Hirschi, C. E. Xu, T. Tsukamoto and R. Sager, "Gap Junction Genes Cx26 and Cx43 Individually Suppress the Cancer Phenotype of Human Mammary Carcinoma Cells and Restore Differentiation Potential," Cell Growth \& Differentiation, Vol. 7, No. 7, 1996, pp. 861-870.

[18] D. W. Laird, P. Fistouris, G. Batist, L. Alpert, H. T. Huynh, G. D. Carystions and M. A. Alaoui-Jamali, "Deficiency of Connexin43 Gap Junctions Is an Independent Marker for Breast Tumors," Cancer Research, Vol. 59, No. 16, 1999, pp. 4104-4110.

[19] R. J. Ruch, K. Cesen-Cummings and A. Malkinson, "Role of Gap Junctions in Lung Neoplasia," Experimental Lung Research, Vol. 24, No. 4, 1998, pp.523-539. doi:10.3109/01902149809087384

[20] R. P. Huang, M. Z. Hossain, A. Sehgal and A. L. Boynton, "Reduced Connexin43 Expression in High-Grade Human Brain Glioma Cells," Journal of Surgical Oncology, Vol. 70, No. 1, 1999, pp. 21-24.

doi:10.1002/(SICI)1096-9098(199901)70:1<21::AID-JSO 4>3.0.CO;2-0

[21] K. Willecke, J. Eiberger, J. Degen, D. Eckardt, A. Romualdi, M. Guldenagel and G. Sohl, "Structural and Functional Diversity of Connexin Genes in the Mouse and Human Genome," Biological Chemistry, Vol. 383, No. 5, 2002, pp. 725-737. doi:10.1515/BC.2002.076

[22] A. Okuma, A. Kuraoka, H. Iida, T. Inai, K. Wasano and Y. Shibata, "Colocalization of Connexin 43 and connexin 45 but Absence of Connexin 40 in Granulosa Cell Gap Junctions of Rat Ovary," The Journal of the Society for Reproduction and Fertility, Vol. 107, No. 2, 1996, pp. 255-264. doi:10.1530/jrf.0.1070255

[23] M. S. Risley, I. P. Tan, C. Roy and J. C. Saez, "Cell-, Age- and Stagedependent Distribution of Connexin43 Gap Junctions in Testes," Journal of Cell Science, Vol. 103, No. 1, 1992, pp. 81-96.

[24] Y. Kato, T. Hirano, K. Yoshida, K. Yashima, S. Akimoto, 
K. Tsuji, T. Ohira, M. Tsubol, N. Ikeda, Y. Ebihara and H. Kato, "Frequent Loss of E-Cadherin and/or Catenins in Intrabronchial Lesions during Carcinogenesis of the Bronchial Epithelium," Lung Cancer, Vol. 48, No. 3, 2005, pp. 323-330. doi:10.1016/i.lungcan.2004.11.012

[25] J. T. Chen, Y. W. Cheng, M. C. Chou, T. Sen-Lin, W. W. Lai, W. L. Ho and H. Lee, "The Correlation between Aberrant Connexin 43 mRNA Expression Induced by Promoter Methylation and Nodal Micrometastasis in NonSmall Cell Lung Cancer," Clinical Cancer Reserch, Vol. 9, No. 11, 2003, pp. 4200-4204.

[26] R. Brehm, C. Rüttinger, P. Fischer, I. Gashaw, E. Winterhager, S. Kliesch, R. M. Bohle, K. Steger and M. Bergmann, "Transition from Preinvasive Carcinoma in Situ to Seminoma Is Accompanied by a Reduction of Connexin 43 Expression in Sertoli Cells and Germ Cells," Neoplasia, Vol. 8, No. 6, 2006, pp. 499-509. doi:10.1593/neo.05847

[27] Z. Q. Zhang, Z. X. Lin and Y. L. Han, "Expression of Gap Junction Protein Cx43 in Cultured Normal Human Ernbryonic Lung Cells and Lung Carcinoma Cells," Acta Biophysics Sinica (in Chinese), Vol. 4, 1994, pp. 411-413.

[28] J. I. Morgan and T. Curran, "Role of Ion Flux in the Control of c-fos Expression," Nature, Vol. 322, No. 6079, 1986, pp. 552-555. doi:10.1038/322552a0

[29] D. Carson and J. Ribeiro, "Apoptosis and Disease," Lancet, Vol. 341, No. 8855, 1993, pp. 1251-1258. doi:10.1016/0140-6736(93)91154-E

[30] W. M. Jongen, D. J. Fitzgerald, M. Asamoto, C. Piccoli, T. J. Slaga, D. Gros, M. Takeichi and H. Yamasaki, "Regulation of Connexin43-Mediated Gap Junctional Intercellular Communication by $\mathrm{Ca}^{2+}$ in Mouse Epidermal Cells Is Controlled by E-Cadherin," Journal of Cell Biology, Vol. 144, No. 3, 1991, pp. 545-555. doi:10.1083/jcb.114.3.545

[31] C. S. Yang and Z. Y. Wang, "Tea and Cancer," Journal of the National Cancer Institute, Vol. 85, No. 3, 1993, pp. 1038-1049. doi:10.1093/jnci/85.13.1038

[32] C. S. Yang, P. Maliakal and X. Meng, "Inhibition of Carcinogenesis by Tea," Annual Reviews Pharmacology and Toxicology., Vol. 42, No. 1, 2002, pp. 25-54. doi:10.1146/annurev.pharmtox.42.082101.154309

[33] J. Ju, G. Lu, J. D. Lambert and C. S. Yang, "Inhibition of Carcinogenesis by Tea Constituents," Seminars in Cancer Biology, Vol. 17, No. 5, 2007, pp. 395-402. doi:10.1016/j.semcancer.2007.06.013

[34] C. S. Yang, X. Wang, G. Lu and S. C. Picinich, "Cancer Prevention by Tea: Animal Studies, Molecular Mechanisms and Human Relevance," National Reviews Cancer, Vol. 9, No. 6, 2009, pp. 429-439. doi:10.1038/nrc2641

[35] J. V. Higdon and B. Frei, "Tea Catechins and Polyphenols: Health Effects, Metabolism, and Antioxidant Functions," Critical Reviews in Food Science and Nutrition, Vol. 43, No. 1, 2003, pp. 89-143. doi: $10.1080 / 10408690390826464$

[36] V. Crespy and G. Williamson, "A Review of the Health Effects of Green Tea Catechins in Vivo Animal Models," The Journal of Nutrition, Vol. 134, No. 12, 2004, pp.
3431S-3440S.

[37] J. Y. Ju, G. Lu, D. J. Lambert and C. S. Yang, "Inhibition of Carcinogenesis by Tea Constituents," Seminars in Cancer Biology, Vol. 17, No. 5, 2007, pp. 395-402. doi:10.1016/j.semcancer.2007.06.013

[38] H. Mukhtar, S. K. Katiyar and R. Agarwal, "Green Tea and Skin-Anticarcinogenic Effects," Journal of Investigative Dermatology, Vol. 102, No. 1, 1994, pp. 3-7. doi:10.1111/1523-1747.ep12371720

[39] I. E. Dreosti, M. J. Wargovich and C. S. Yang, "Inhibition of Carcinogenesis by Tea: The Evidence from Experimental Studies," Critical Reviews in Food Science and Nutrition, Vol. 37, No. 8, 1997, pp. 761-770. doi:10.1080/10408399709527801

[40] F. L. Chung, J. Schwartz, C. R. Herzog and Y. M. Yang, "Tea and Cancer Prevention: Studies in Animals and Humans," The Journal of Nutrition, Vol. 133, No. 10, 2003, pp. $3268 \mathrm{~S}-3274 \mathrm{~S}$.

[41] J. D. Lambert, J. Hong, G. Y. Yang, J. Liao and C. S. Yang, "Inhibition of Carcinogenesis by Polyphenols: Evidence from Laboratory Investigations," The American Journal of Clinical Nutrition, Vol. 81, No. 1, 2005, pp. 284S-291S.

[42] D. M. Parkin, "Global Cancer Statistics in the Year 2000," Lancet Oncology, Vol. 2, No. 9, 2001, pp. 533-543. doi:10.1016/S1470-2045(01)00486-7

[43] D. M. Parkin, F. Bray, J. Ferlay and P. Pisani, "Global Cancer Statistics, 2002," CA: A Cancer Journal of Clinicians, Vol. 55, No. 2, 2005, pp. 74-108. doi:10.3322/canjclin.55.2.74

[44] S. Valcic, B. N. Timmermann, D. S. Alberts, G. A. Wachter, M. Krutzsch, J. Wymer and J.M. Guillen, "Inhibitory Effect of Six Green Tea Catechins and Caffeine on the Growth of Four Selected Human Tumor Cell Lines," Anti-Cancer Drugs, Vol. 7, No. 4, 1996, pp. 461-468. doi:10.1097/00001813-199606000-00011

[45] S. Okabe, M. Suganuma, M. Hayashi, E. Sueoka, A. Komori and H. Fujiki, "Mechanisms of Growth Inhibition of Human Lung Cancer Cell Line, PC-9, by Tea Polyphenols," Cancer Science, Vol. 88, No. 7, 1997, pp. 639-643. doi:10.1111/j.1349-7006.1997.tb00431.x

[46] C. S. Yang, J. Liao, G. Y. Yang and G. Lu, "Inhibition of Lung Tumorigenesis by Tea," Experimental Lung Research, Vol. 31, No. 1, 2005, pp. 135-144. doi: 10.1080/01902140490495525

[47] T. Kuzuhara, A. Tanabe, Y. Sei, K. Yamaguchi, M. Suganuma and H. Fujiki, "Synergistic Effects of Multiple Treatments, and both DNA and RNA Direct Bindings on, Green Tea Catechins," Molecular Carcinogenesis, Vol. 46, No. 8, 2007, pp. 640-645. doi:10.1002/mc.20332

[48] D. Sadava, E. Whitlock and S. E. Kane, "The Green Tea Polyphenol, Epigallocatechin-3-gallate Inhibits Telomerase and Induces Apoptosis in Drug-Resistant Lung Cancer Cells," Biochemical and Biophysical Research Communications, Vol. 360, No. 1, 2007, pp. 233-237. doi:10.1016/j.bbrc.2007.06.030

[49] C. Q. Yong, Y. Q. Wu, Y. Q. Jiang and X. Xiao, “Adhe- 
sion Molecules in the Blood of Lung Cancer Metastasis and the Role of Polyphenols in the Regulation," Journal of Military Medicine, Vol. 27, No. 4, No. , 2002, pp. 339344.

[50] H. Yamasaki, M. Mesnil, Y. Omori, N. Mironov and V. Krutovskikh, "Intercellular Communication and Carcinogenesis," Mutation Research, Vol. 333, No. 1-2, 1995, pp. 181-188. doi:10.1016/0027-5107(95)00144-1

[51] E. Tomai, H. Brownell, T. Tufescu, K. Reid, B. G. Campling and L. Raptis, "Gap Junctional Intercellular Communication in Cultured Human Lung Carcinoma Cells," Lung Cancer, Vol. 23, No. 3, 1999, pp. 223-231. doi:10.1016/S0169-5002(99)00016-1

[52] P. Pu, Z. Xia, S. Yu and Q. Huang, "Altered Expression of Cx43 in Astrocytic Tumors," Clinical Neurology and Neurosurgery, Vol. 107, No. 1, 2004, pp. 49-54. doi:10.1016/j.clineuro.2004.03.006

[53] L. Soroceanu, T. J. Manning Jr. and H. Sontheimer, "Reduced Expression of Connexin-43 and Functional Gap Junction Coupling in Human Gliomas," Glia, Vol. 33, No. 2, 2001, pp. 107-117. doi:10.1002/1098-1136(200102)33:2<107::AID-GLIA10 $10>3.0 . \mathrm{CO} ; 2-4$

[54] D. Laird, P. Fisturis, G. Batist, L. Alpert, H. T. Huynh, G. D. Carystinos and M. A. Alaoui-Jamali, "Deficiency of Connexin 43 Gap Junctions Is an Independent Marker for Breast Tumors," Cancer Research, Vol. 59, No. 16, 1999, pp. 4104-4110.

[55] O. Traub, R. Eckert, H. Lichtenberg-Fraté, C. Elfgang, B. Bastide, K. H. Scheidtmann, D. F. Hülser and K. Willecke, "Immunochemical and Electrophysiological Characterization of Murine Connexin 40 and 43 in Mouse Tissues and Transfected Human Cells," European Journal of Cell Biology, Vol. 64, No. 1, 1994, pp. 101-112.

[56] J. E. Trosko and R. J. Ruch, "The Role of Cell-Cell Communication in Carcinogenesis," Frontiers in Bioscience, Vol. 3, 1998, pp. 208-236.

[57] R. W. Banoub, M. Fernstrom, A. M. Malkinson and R. J. Ruch, "Enhancement of Gap Junctional by Dibutyryl Cyclic AMP in Lung Epithelial Cells," Anti-Cancer Research, Vol. 16, No. 6B, 1996, pp. 3715-3719.

[58] T. Toyofuku, M. Yabuki, K. Otsu, T. Kuzuya, M. Hori and M. Tada, "Intercellular Calcium Signaling via Gap Junction in Connexin 43 Transfected Cells," Journal of Biological Chemistry, Vol. 273, No. 3, 1998, pp. 15191528. doi:10.1074/jbc.273.3.1519

[59] Q. Shao, H. Wang, E. McLachlan, G. I. Veitch and D. W.
Laird, "Down-Regulation of Cx43 by Retroviral Delivery of Small Interfering RNA Promotes an Aggressive Breast Cancer Cell Phenotype," Cancer Research, Vol. 65, No. 7, 2005 , pp. 2705-2711. doi:10.1158/0008-5472.CAN-04-2367

[60] X. Xu, R. Francis, C. J. Wei, K. L. Linask and C. W. Lo, "Connexin 43-Mediated Modulation of Polarized Cell Movement and the Directional Migration of Cardiac Neural Crest Cells," Development, Vol. 133, No. 18, 2006, pp. 3629-3639. doi:10.1242/dev.02543

[61] J. H. Lin, T. Takano, M. L. Cotrina, G. Arcuino, J. Kang, S. Liu, Q. Gao, L. Jiang, F. Li, H. Lichtenberg-Frate, S. Haubrich, K. Willecke, S. A. Goldman and M. Nedergaard, "Connexin 43 Enhances the Adhesivity and Mediates the Invasion of Malignant Glioma Cells," Journal of Neuroscience, Vol. 22, No. 11, 2002, pp. 4302-4311.

[62] R. Oliveira, C. Christov, J. S. Guillamo, S. de Bouard, S. Palfi, L. Venance, M. Tardy and M. Peschanski, "Contribution of Gap Junctional Communication between Tumor Cells and Astroglia to the Invasion of the Brain Parenchyma by Human Glioblastomas," BMC Cell Biology, Vol. 6, No. 1, 2005, pp. 7-21. doi:10.1186/1471-2121-6-7

[63] W. Zhang, C. Nwagwu, D. M. Le, V. W. Yong, H. Song and W. T. Couldwell, "Increased Invasive Capacity of Connexin43-Overexpressing Malignant Glioma Cells," Journal of Neurosurgery, Vol. 99, No. 6, 2003, pp. 10391046. doi:10.3171/jns.2003.99.6.1039

[64] L. A. Elias, D. D. Wang and A. R. Kriegstein, "Gap Junction Adhesion Is Necessary for Radial Migration in the Neocortex," Nature, Vol. 448, No. 7156, 2007, pp. 901907. doi:10.1038/nature06063

[65] C. Cina, K. Maass, M. Theis, K. Willecke, J. F. Bechberger and C. C. Naus, "Involvement of the Cytoplasmic CTerminal Domain of Connexin43 in Neuronal Migration," Journal of Neuroscience, Vol. 29, No. 7, 2009, pp. 20092021. doi:10.1523/JNEUROSCI.5025-08.2009

[66] Y. W. Zhang, M. Kaneda and I. Morita, "The Gap Junction-Independent Tumor-Suppressing Effect of Connexin 43," Journal of Biological Chemistry, Vol. 278, No. 45, 2003, pp. 44852-44856. doi:10.1074/jbc.M305072200

[67] D. C. Bates, W. C. Sin, Q. Aftab and C. C. Naus, "Connexin43 Enhances Glioma Invasion by a Mechanism Involving the Carboxy Terminus," Glia, Vol. 55, No. 15, 2007, pp. 1554-1564. doi:10.1002/glia.20569

[68] W. C. Sin, S. Crespin and M. Mesnil, "Opposing Roles of Connexin43 in Glioma Progression," Biochimica et Biophysica Acta, Vol. 10, No. 4C, 2011, pp. 4-6. 